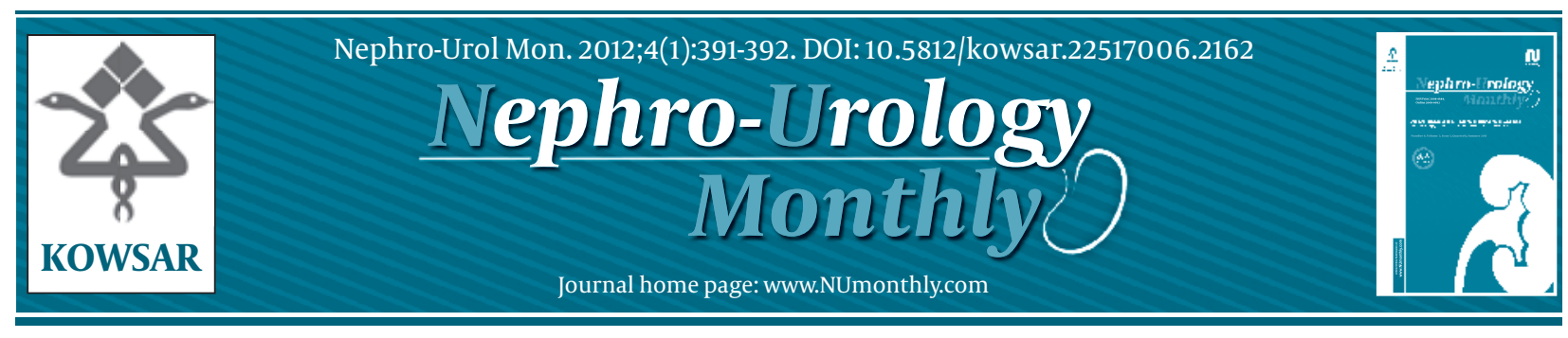

\title{
Diabetes and Hepatitis C Infection in Dialysis Patients: The Present Situ- ation in Japan
}

\author{
Akira Sugawara ${ }^{{ }^{*}}$, Hiroshi Sato ${ }^{2}$, Sadayoshi Ito ${ }^{3}$ \\ ${ }^{1}$ Department of Pathophysiology, Tohoku University Graduate School of Medicine, Sendai, Japan \\ 2 Department of Clinical Pharmacology and Therapeutics, Tohoku University Graduate School of Pharmaceutical Sciences and Medicine, Sendai, Japan \\ ${ }^{3}$ Division of Nephrology, Endocrinology and Vascular Medicine, Tohoku University Graduate School of Medicine, Sendai, Japan
}

\section{A R T I C L E I N F O}

Article type:

Letter to Editor

Article history:

Received: 26 Aug 2011

Revised: 05 Sep 2011

Accepted: 14 Sep 2011

\section{Keywords:}

Diabetes Mellitus

Hepatitis C

Renal Dialysis

\section{Dear Editor,}

We read with interest the paper of Alavian SM (1), recently published in Nephro-Urology Monthly, which focused on the importance of the control of HCV and metabolic syndrome in patients with chronic renal failure (CRF). In Japan, the number of diabetic patients is also increasing year-by-year, and the number of patients with diabetic nephropathy among new patients started on dialysis surpassed those with chronic glomerulonephritis since 1998 (2). In order to reduce the number of new diabetic patients, the Ministry of Health, Labour and Welfare in Japan introduced an obligatory medical examination for metabolic syndrome in 2008 (3).

Hepatitis C virus (HCV) infection is known to be strongly associated with chronic kidney disease (CKD) including membranoproliferative glomerulonephritis (MPGN) with cryoglobulinaemia $(4,5)$. In Japan, Iwasa Y et al. (6) reported that the prevalence rate of HCV infection (deter-

* Corresponding author: Akira Sugawara, Department of Pathophysiology, Tohoku University Graduate School of Medicine, 2-1 Seiryo-machi, Aoba-ku, 980-8575 Sendai, Japan. Tel:+81-227177483, Fax: +81-227178083,

E-mail:akiras2i@med.tohoku.ac.jp

DOI:10.5812/kowsar.22517006.2162

Copyright $\odot 2012$, Kowsar M.P.Co. All rights reserved.
- Please cite this paper as:

Sugawara A, Sato H, Ito S. Diabetes and Hepatitis C Infection in Dialysis Patients: The Present Situation in Japan. Nephro-Urol Mon.2012;4(1):391-2. DOI: 10.5812/kowsar.22517006.2162

Copyright $\odot 2012$, Kowsar M.P.Co. All rights reserved.

mined by the anti-HCV antibody positivity) among new patients started on hemodialysis was $7.3 \%$, in contrast to $0.15 \%$ in healthy volunteers. They also demonstrated the higher frequency of diabetic nephropathy in antiHCV antibody-positive patients (37.9\%) than in antiHCV antibody-negative patients (18.6\%) (6). Soma J et al. (7) reported the prevalence rate of anti-HCV antibody positivity among 2370 renal biopsied patients in the northeast region (Tohoku) of Japan. Among the patients, 4.1\% (97 of 2370) were anti-HCV antibody-positive, while $19.5 \%$ patients (24 of 123) with type 2 diabetic-related glomerulosclerosis (II-DGS) and $18.2 \%$ patients (10 of 55) with MPGN were anti-HCV antibody-positive (7). Interestingly, $25 \%$ of patients ( 6 of 24 ) with II-DGS had other co-existing glomerular diseases including 3 with MPGN (7). They also demonstrated significantly low renal survival rate and steep $1 / S_{\text {cr }}$ slope in II-DGS patients with anti-HCV antibody positivity compared to those with anti-HCV antibody negativity (7), directly indicating the adverse effects of HCV infection on patients with diabetic nephropathy.

In Japan, donor blood for transfusion has been routinely screened for HCV infection since 1989 (6). Due to the blood screening and the innovation of recombinant erythropoietin, the risk of HCV infection by 
blood transfusion has significantly reduced in dialysis patients (8). However, hospital-acquired infection of HCV has occasionally been reported and a mass infection case occurred in a private hospital in Hyogo prefecture in May 1999. In order to prevent hospital-acquired HCV infection, the Ministry of Health, Labour and Welfare in Japan thereafter published guidelines for the prevention of hospital-acquired infection during dialysis procedures for both doctors and paramedical staffs in 1999 (9). The guidelines have been revised twice and seem to have contributed to reducing hospital-acquired HCV infection. The prevalence rate of anti-HCV antibody positivity among the entire Japanese dialysis population decreased from $15.95 \%$ (1999) to $9.83 \%$ (the end of 2007) $(9,10)$. Additionally, the positive conversion ratio of the anti-HCV antibody, which most likely represents the occurrence of hospital-acquired HCV infection, among the entire Japanese dialysis population decreased from $2.1 \%$ (2001) to $1.04 \%$ (2007) (2). These efforts in Japan can be adapted by other countries, and can provide benefits for dialysis patients there.

\section{Finacial disclosures}

The authors have nothing to declare.

\section{References}

1. Alavian SM. Diabetes, renal failure and hepatitis $C$ infection: The puzzle should be attended more in future. Nephro-Urol Mon. 2011;3(3):153-4.

2. Nakai S, Suzuki K, Masakane I, Wada A, Itami N, Ogata S, et al. Overview of regular dialysis treatment in Japan (as of 31 December 2008). Ther ApherDial. 2010;14(6):505-40.

3. Tsushita K, Muramoto A. [The current situation of newly started lifestyle intervention system to reduce metabolic syndrome in Japan-specific health checkup and health guidance]. Nihon Rinsho. 2011;69 (Suppl 1):723-8.

4. Kamar N, Izopet J, Alric L, Guilbeaud-Frugier C, Rostaing L. Hepatitis C virus-related kidney disease: an overview. Clin Nephrol. 2008;69(3):149-60.

5. Perico N, Cattaneo D, Bikbov B, Remuzzi G. Hepatitis C infection and chronic renal diseases. Clin JAm Soc Nephrol. 2009;4(1):207-20.

6. Iwasa Y, Otsubo S, Sugi O, Sato K, Asamiya Y, Eguchi A, et al. Patterns in the prevalence of hepatitis $C$ virus infection at the start of hemodialysis in Japan. Clin Exp Nephrol. 2008;12(1):53-7.

7. Soma J, Saito T, Taguma Y, Chiba S, Sato H, Sugimura K, et al. High prevalence and adverse effect of hepatitis $C$ virus infection in type II diabetic-related nephropathy. J Am Soc Nephrol. 2000;11(4):690-9.

8. Rahnavardi M, Hosseini Moghaddam SM, Alavian SM. Hepatitis $\mathrm{C}$ in hemodialysis patients: current global magnitude, natural history, diagnostic difficulties, and preventive measures. Am J Nephrol. 2008;28(4):628-40.

9. Ando R, Akiba T. The present status of the hospital infection control for the viral hepatitis in hemodialysis facilities. JJap Soc Dial Ther. 2009;42(6):423-33.

10. Nakai S, Masakane I, Shigematsu T, Hamano T, Yamagata K, Watanabe $Y$, et al. An overview of regular dialysis treatment in Japan (as of 31 December 2007). Ther Apher Dial. 2009;13(6):457-504. 